BOJANA VUKOVIĆ, Ph.D. ${ }^{1}$

E-mail: bojanavuk@ef.uns.ac.rs

SUNČICA MILUTINOVIĆ, Ph.D. ${ }^{1}$

(Corresponding author)

E-mail: suncica@ef.uns.ac.rs

VERA MIROVIĆ, Ph.D. ${ }^{1}$

E-mail: vera.mirovic@ef.uns.ac.rs

NIKOLA MILIĆEVIĆ, Ph.D. ${ }^{1}$

E-mail: milicevic.nikola@ef.uns.ac.rs

${ }^{1}$ University of Novi Sad

Faculty of Economics in Subotica

Segedinski put 9-11, 24000 Subotica, Serbia
Transport Logistics Original Scientific Paper Submitted: 12 July 2019 Accepted: 27 Apr. 2020

\title{
THE PROFITABILITY ANALYSIS OF THE LOGISTICS INDUSTRY COMPANIES IN THE BALKAN COUNTRIES
}

\begin{abstract}
The main purpose of this paper is to research the factors that have an impact on the company profitability in the logistics industry during a five-year period (20132017). The sample includes 748 active companies operating in the logistics industry in the Balkan countries. Bearing in mind that logistics is an essential instrument of competitiveness and profitability of the company operations and that logistics is one of the most profitable industries, this paper used the panel data model with fixed effect in order to analyse profitability. The obtained results showed that four out of the six studied variables (company size, tangibility of assets, liquidity, and asset turnover ratio) have a statistically significant impact on profitability. The results provide guidelines for increasing profitability and improving the performance of logistics companies, given that an efficient planning system, managing and controlling the logistics system are key determinants of profitable business operations.
\end{abstract}

\section{KEY WORDS}

profitability; logistics industry; panel data model; Balkan countries;

\section{INTRODUCTION}

Each company is most concerned with its profitability as the main indicator of the bottom line of the company. Regardless of the type of services offered or the products sold, the primary goal of each company is profit maximization, whereas the principal goal of profitability is the rate of return on equity [1]. In defining the motive for this research, the starting point was to set profit as a long-term goal of every company that measures the success of the manufactured product and the services provided on the one hand, and the development of its market, on the other. Given that profitable companies create added value, recruit staff and promote innovation, growth and development, the motives for this research lie in the need to explore the factors that drive changes in the profitability levels. Likewise, the sustainability of a company is conditioned by its ability to generate profits. Companies that operate with low-profit values or whose profits record fluctuations in value are questioning sustainability over a long period of time. In this respect, profitability cannot be considered individually but in relation to other factors. It is influenced by numerous factors from the internal and external environment of the company which can be taken as incentives and constraints, and some of them are more or less conditioned by certain conditions of the industry in which the company operates [2]. So, the paper should be identified the indicators of profitability proxied by ROA and ROE and quantified by their relative importance.

There is a significant relationship between the profitability of each company and the costs of logistics activities that make up a significant portion of the total business costs. In today's business environment, there is an expressed strong need to control logistics costs and in such circumstances the performance measurement of companies is a successful means of achieving business goals [3]. The survey conducted by Škerlič and Muha showed that companies that have developed systems to control logistics costs, face fewer problems during business processes [4]. Bearing in mind that the optimization of logistics activities is necessary in the context of maintaining the profitability of each company, and 
that logistics sector is one of the most profitable ones and attractive to a large number of companies seeking to improve their market position and increase profits, the starting issue was to explain how to maintain and improve the profitability of the logistics industry companies. In this direction, the readers will gain insight into the factors that contribute to the profitability of the logistics industry companies.

There are several previous studies that have examined the issue of profitability within the logistics industry. It was discussed in the research of Dayou [5], Hofmann et al. [6], Mothilal et al. [7], Panayides [8], Parola et al. [9]. Dayou [5] found that it is lower level profitability, rather than marketability efficiency which poses the greater challenge for the logistics companies. This, in turn, means that logistics companies should make greater efforts in the field of profit-generating activities. The present research is focused on exploring the ways of profit generating in logistics companies and finding indicators of significant impact on the profitability in this industry. Hofmann et al. [6] used the financial statement analysis to identify the most significant indicators for high profitability. Their work underlined the need for further research focusing on micro-financial aspects of asset, capital, liquidity and profitability structure. Hence, present authors study these micro-financial aspects of profitability using a much more advanced methodology of the panel regression analysis. Analysing the main performance indicators of the Turkish logistics industry companies by Analytic Network Process method, Kucukaltan et al. observed fifteen indicators and proposed a model with the four most important indicators that include educated employee (15.61\%), managerial skills (14.78\%), cost (13.50\%) and profitability (10.36\%) [10]. Accordingly, profitability stands out as one of the prime factors to be focused on by logistics industry managers.

Previous research focused mainly on profitability analysis, on the one hand, or the business analysis of companies of the logistic sector, on the other. To the authors' knowledge, profitability of the logistics companies based on the specific indicators that increase profitability has not been thoroughly researched. Only Saripalle [11] analysed the determinants of profitability in the Indian logistics industry by panel data model and found that the capital structure, liquidity and market share have a significant impact on profitability. Considering that the application of these results is limited to markets such as those where Indian logistics companies have operated in, the purpose of the paper was to develop a model which indicated the determinants of improving profitability of the logistics companies in the Balkan countries. The aim of the conducted research was reflected in providing answers to the following questions:

1) What are the internal factors that affect profitability of logistics companies in the Balkan countries?

2) What is the relationship between identified internal factors and profitability in the logistics sector of the Balkan countries?

So, the paper has answered how profitability can be affected and what factors would ensure the profit growth, bearing in mind that highly profitable logistics companies are characterized by an understanding of key success factors and proactive positioning. The indicators were selected based on the previously validated empirical studies of the factors affecting profitability and on the available data in the financial statements of the logistics companies. The starting point of the research is that the financial statements of the logistics companies truly and objectively reflect their financial position, results of operations and cash flows, as they are contained in a TP Catalyst database with information on more than 360 million companies in all countries worldwide that provides the highest quality data [12]. True and objective reporting of assets, capital, liabilities, results and cash flows of an entity is an instrument of protecting the interests of the creditor and owner of the capital. Likewise, the quality of internal and external stakeholder's decisions is determined by the completeness and reliability of the information presented in financial statements.

Considering the importance of profitability, numerous authors have explored the factors that affect the company profitability. For example, Boadi et al. [13], Burja [14], Serrasqueiro [15], Alarussi and Alhaderi [16] among others, researched the effect of leverage on the level of profitability. The effect of company size measured by sales on profitability was tested by Agiomirgianakis et al. [17], Abu-Tapanjeh [18], Asimakopoulos et al. [19], Banchuenvijit [20], among others. On the other hand, the effect of company size measured by assets on profitability was investigated in the research conducted by Malik [21], Lee [22], Lazăr [23], among others. The relationship between tangibles and profitability was 
explored by Al-Jafari and Al Samman [24], Pratheepan [25] and Bhutta and Hasan [26], among others. Similarly, the impact of current liquidity on the profitability was researched by Goddard et al. [27], Devi and Devi [28], Charumathi [29], among others. The relationship between efficiency and profitability was researched by Chander and Aggarwal [30], Abey and Velmurugan [31], Alarussi and Alhaderi [16], Pervan et al. [32], among others. Lastly, the impact of growth in sales on profitability was analysed by Mijić et al. [33], Maçãs Nunes et al. [34], Yazdanfar [35], Denčić-Mihajlov [36], among others. So, profitability was influenced by different factors and the previously conducted studies investigating the association between factors and profitability have yielded different results.

There has been no research to date on profitability analysis of the logistics sector on the level of the Balkan countries. Further, the previously obtained results have their limitations on the level of the Balkan countries, which led the authors to conduct a thorough study of the profitability of logistics companies in the following ten Balkan countries: Albania, Bulgaria, Bosnia and Herzegovina, Croatia, Montenegro, North Macedonia, Romania, Serbia, Slovenia and Greece. The sample included 748 active companies in the mentioned field of industry. The panel data model with fixed effect was used in order to evaluate the impact of factors on profitability.

The findings of this study contribute to a better understanding of profitability, by examining which factors best explain the profitability of logistics companies in the Balkan countries. The developing of models with determinants of profitability should ensure and improve the yield performance of logistics industry companies. Determining the factors that lead to difference in the level of the company profitability is especially important for business executives of logistics companies when making a decision to expand the company business or survive for an extended period of time. The results also contribute to the policy makers regardless of whether they are inside or outside of the logistics companies. The results also contribute to managers of logistics companies in making decisions regarding maintaining and improving their competitive position and deciding on the use of available economic resources in the future. The efficiency of managers of logistics industry companies is often conditioned by the ability to identify those indicators.
The paper consists of five sections. The Theoretical Background that outlines the objectives of the research was presented in the second section following the introduction. This is followed by Data and Methodology that consists of explanation of dependent and independent variables, sample and methodology. The outcomes are presented in the section Results and Discussion, while the Conclusion of the paper summarizes the limitations and guidelines for future research.

\section{THEORETICAL BACKGROUND}

Profitability is vital for every company business. If the company does not operate profitably, if it generates low-profit values, or the value of profit shows constant fluctuations, the company survival is often under threat. This means that profitability is seen as a vital prerequisite for the survival and success of the company in the long run. One of the main objectives of financial management is to maximize the owners' wealth or otherwise, to realize the ownership interests, thus financial management must focus on profitability. The efficiency of the company financial management is reflected in the ability to encourage the authorities to recognize the elements that influence the improvement of profitability, and consequently, the overall performance of the company as well.

Earlier research considered the profitability of companies from various regions, countries, and economy sectors through numerous company-specific and micro-specific determinants. A closer look at recent research has revealed their common features in terms of selected profitability determinants. Therefore, six determinants of profitability were selected. The criteria for selecting the variables were as follows:

1) Analysis of the previous research and variables used, and

2) Available data in the financial statements.

A detailed explanation of the determinants and their justified selection based on earlier research follows below.

Leverage shows the extent to which the total assets of the company are funded by debts i.e. the extent to which a company finances investments using other sources of financing. A growth in dynamics ensures an increase in the amount of the company financing sources, but also leads to less autonomy and financial solvency [14]. With respect to leverage, there are two opposing views concerning the 
effects on company profitability. Many authors have found a negative effect of leverage on company profitability $[15,16,24,27,34,38,39,40]$. All these studies have shown that the level of profitability is greater with low-leverage companies. Agiomirgianakis et al. [17] explained negatively related leverage to profitability in the following manner "when a large part of earnings is ear-marked to cover interest payments, less funds are available for reinvestment, thus reducing the growth opportunities of the company".

However, certain studies confirmed a positive relationship. Boadi et al. [13] discovered that there was a positive relationship between leverage and profitability of insurance companies in Ghana. Burja [14] also found that leverage had a positive influence on profitability within the chemical industry.

Company size can be measured as a Natural Logarithm of Sales. Regarding the size of a company, again, there are also two opposing views concerning the effects on company profitability. According to Agiomirgianakis et al. [17], larger companies are more profitable than the smaller ones. This could be consistent with the impact of scale economies ensuring a lower average cost. Among others, this result is supported by the fact that larger enterprises can negotiate better prices/terms for their production inputs. Abu-Tapanjeh [18] and Dhawan [37] also found a negative relationship between company size and profitability.

Conversely, a great number of authors found that size and profitability are positively correlated. The level of profitability is greater with large-size companies because company size positively influences the level of profit [31]. Alarussi and Alhaderi [16] stated that as the size of the company increases, it becomes easier to access more financial resources, which, in turn, leads to lower cost of capital and higher profit. Analysing Greek non-financial companies, Asimakopoulos et al. [19] found that larger companies take advantage of their position in negotiating the price for their inputs, consequently reducing their average cost-improving profitability. Additionally, this finding may also imply the better adaptation of the larger companies to the new macroeconomic environment that had a positive effect on their profitability. Doğan [39] observed a positive relation between size and profitability in the financial sector in Turkey, and Al-Jafari and Al Samman [24] revealed that the same holds true for the industrial sector in Oman. A positive relationship between size and profitability was also identified by Pratheepan [25], who concluded that larger companies have the opportunity to negotiate with their material suppliers to reduce the cost as well as increase the profitability. Moreover, Banchuenvijit [20] noted that profitability is positively related to size in terms of total sales.

Company size can also be measured as a Logarithm of Total Assets. The results of recent research $[21,40]$ have revealed a positive size - profitability relationship. Lee [22] found that larger companies tended to generate higher profitability but the rate of profit gains were going down as companies continued to grow. According to Pervan et al. [32] large companies can hire more skilled managers, adopt new production procedures or reform the current one, employ new technologies, have more capital, and can be generally more innovative than their smaller competitors. Larger companies may also use their reputation as an advantage or may have better-quality products, enabling them to charge higher prices than their smaller counterparts and therefore, earn higher profits. Despite this, some studies confirmed that the company size in terms of total assets is negatively related to profitability [19,23].

Tangibility expresses the share of assets that the company disposes of permanently for its activities and indicates the level of capital investment in the technical and productive infrastructure. Burja [14] stated that a high level of this indicator points towards an active investment policy, but once this growth surpasses a certain level (50\%), it may lead to an efficient use of the working capital and limit the ability to expand the current activities. This positive relationship between the tangibility and profitability was confirmed by Al-Jafari and Al Samman [24] in their research of industrial companies in Oman. Bhutta and Hasan [26] highlighted that if a company had less tangibility of assets, it would be more profitable.

Despite the aforementioned, Banchuenvijit [20] claimed that tangibility was negatively related to profitability in the listed companies of Vietnam. In his research he suggested that the higher ratio of fixed assets to total assets leads to an inefficient use of working capital, or low cash reserve. Boadi et al. [13], Burja [14], and Lazăr [23] also stated that tangibility had a negative relationship to profitability. According to Pratheepan [25] there is a negative relationship between asset tangibility and profitability, due to the fact that manufacturing companies with a higher level of tangible assets are the ones 
that present lower levels of profitability. Thus, companies that are more inclined to invest in research and development activities, and consequently innovate, are the ones with greater profitability.

Current liquidity represents the ability of a company to cover current liabilities with available current assets. Alarussi and Alhaderi [16] identified a negative relationship between liquidity and profitability analysing the Malaysian non-financial listed companies, because profitability does not depend on cash base, and liquidity is important in financial institutions, such as banks, but not in non-financial companies. Liquidity is negatively correlated with profitability, as Devi and Devi [28] claimed, because a rise in liquidity normally provided increase to decline in profitability planes due to the opportunity cost of holding cash rather than investing it.

Goddard et al. [27] investigated the determinants of profitability in the field of the European manufacturing and service industries and found that profitability was positively related to liquidity. They concluded that companies which remained liquid had the flexibility, i.e. were able to adapt rapidly to changing circumstances and it was highly likely that this adaptability had a beneficial effect on profitability. Charumathi [29] and Doğan [39] also stated in their studies that liquidity exerted positive influence on profitability.

Efficiency of the company shows the ability of the company available assets to result in an effect that is most often expressed in terms of sales revenue. The efficiency is the cornerstone to achieve higher profits [16]. The efficiency of a company as measured by assets turnover ratio positively influences its profitability, as seen in the Indian drugs and pharmaceutical industry [30]. Abey and Velmurugan [31] found that assets turnover ratio positively influenced the level of profit and noticed that the level of profitability was greater with companies which utilized their assets optimally. Positive relationship was confirmed by Lee [22] and Pervan et al. [32]. Despite these findings, Islam and Khan [40] found that the sales to total asset ratio had a negative effect on the company profitability.

Growth in sales measures the ability of the company to achieve growth in sales. Growth is calculated as the growth rate of sales in two consecutive periods [33]. The positive growth - profitability relationship shows that the level of profitability is higher in companies where growth in sales has been noticed [31]. Asimakopoulos et al. [19] suggested that the growth in sales was positively related to profitability in non-financial companies in Greece. They noticed that a company that manages to increase its sales output would improve its revenues, as well as have more funds available for further expansion. Mijić et al. [33] stated that the growth in sales positively influences the profitability of small and medium-sized entities in the Serbian wholesale and retail sector. Maçãs Nunes et al. [34] concluded that the growth positively influences the profitability of the Portuguese service industry. The relationship between growth and profitability in Portuguese companies is also supported by Serrasqueiro's research [15]. The empirical results from investigating a large sample of Swedish micro firms in four industry sectors suggest that growth positively influences the company profitability [35]. There are more studies with results indicating a positive relationship between growth and profitability of a company, for example, Denčić-Mihajlov [36] and Lazăr's [23] research.

The expected effects of the selected profitability determinants were formulated, as presented in Table 1, based on a comprehensive literature survey that includes the applied determinants and the most significant results. The methodology used in the previous research is presented in Table 2.

Bearing in mind all the previous research and based on the results presented by Alarussi and Alhaderi [16], the following objectives of the research were set:

1) to examine the relationship between logistics company leverage and profitability;

2) to examine the relationship between logistics company size and profitability;

3) to examine the relationship between logistics company tangibility and profitability;

4) to examine the relationship between logistics company liquidity and profitability;

5) to examine the relationship between logistics company efficiency and profitability;

6) to examine the relationship between logistics company growth and profitability.

\section{DATA AND METHODOLOGY}

Panel regression analysis was implemented in this study in order to research the indicators that have a determining effect on the profitability of logistics companies related to warehousing and support activities for transportation. This area includes companies whose primary business activities are 
Vuković B, et al. The Profitability Analysis of the Logistics Industry Companies in the Balkan Countries

Table 1 - Explanatory indicators used in the research and findings in literature review

\begin{tabular}{|c|c|c|}
\hline Explanatory indicators & Positive effect: supported research & Negative effect: supported research \\
\hline Leverage & Boadi et al. [13]; Burja [14] & $\begin{array}{l}\text { Goddard et al. [27]; Maçãs Nunes et al. } \\
\text { [34]; Serrasqueiro [15]; Eriotis et al. [38]; } \\
\text { Doğan [39]; Al-Jafari and Al Samman, } \\
\text { [24]; Alarussi and Alhaderi [16]; Islam and } \\
\text { Khan [40]; Agiomirgianakis et al. [17] } \\
\end{array}$ \\
\hline $\begin{array}{l}\text { Company size measured } \\
\text { by sales }\end{array}$ & $\begin{array}{l}\text { Abey and Velmurugan [31]; Alarussi and Alhaderi } \\
\text { [16]; Asimakopoulos et al. [19]; Doğan [39]; Al-Jafari } \\
\text { and Al Samman [24]; Pratheepan [25]; Banchuenvi- } \\
\text { jit [20]; Serrasqueiro [15]; Bhutta and Hasan [26]; } \\
\text { Denčić-Mihajlov [36] }\end{array}$ & $\begin{array}{l}\text { Agiomirgianakis et al. [17]; Abu-Tapanjeh } \\
\text { [18]; Dhawan [37] }\end{array}$ \\
\hline $\begin{array}{l}\text { Company size measured } \\
\text { by assets }\end{array}$ & $\begin{array}{l}\text { Islam and Khan [40]; Malik [21]; Lee [22]; Pervan et } \\
\text { al. [32] }\end{array}$ & Banchuenvijit [20]; Lazăr [23] \\
\hline Tangibles & $\begin{array}{l}\text { Burja [14]; Al-Jafari and Al Samman [24]; Bhutta and } \\
\text { Hasan [26] }\end{array}$ & $\begin{array}{l}\text { Banchuenvijit [20]; Boadi et al. [13]; Burja } \\
\text { [14]; Lazăr [23]; Pratheepan [25] }\end{array}$ \\
\hline Current liquidity & Goddard et al. [27]; Charumathi [29]; Doğan [39] & $\begin{array}{l}\text { Alarussi and Alhaderi [16]; Devi and Devi } \\
\text { [28] }\end{array}$ \\
\hline Efficiency & $\begin{array}{l}\text { Chander and Aggarwal [30]; Abey and Velmurugan } \\
\text { [31]; Alarussi and Alhaderi [16]; Denčić-Mihajlov } \\
\text { [36]; Lee [22]; Pervan et al. [32] }\end{array}$ & Islam and Khan [40] \\
\hline Growth in sales & $\begin{array}{l}\text { Abey and Velmurugan [31]; Asimakopoulos et al. [19]; } \\
\text { Mijić et al. [33]; Maçãs Nunes et al. [34]; Serrasqueiro } \\
\text { [15]; Yazdanfar [35]; Denčić-Mihajlov [36]; Lazăr [23] }\end{array}$ & \\
\hline
\end{tabular}

Table 2 - The methodology used in the previous research

\begin{tabular}{|c|c|}
\hline Authors & Methodology applied in the research \\
\hline Burja [14] & Multifactor regression analysis \\
\hline Goddard et al. [27] & Panel data model \\
\hline Maçãs Nunes et al. [34] & Dynamic Panel data model \\
\hline Serrasqueiro [15] & Dynamic Panel data model \\
\hline Eriotis et al. [38] & Ordinary Least Square Regression \\
\hline Doğan [39] & Multiple Regression Analysis \\
\hline Al-Jafari and Al Samman [24] & Panel Ordinary Least Squares model \\
\hline Alarussi and Alhaderi [16] & Pooled Ordinary Least Squares Regression \\
\hline Islam and Khan [40] & Random-effects Panel data model \\
\hline Agiomirgianakis et al. [17] & Panel EGLS (Cross-section weights) method \\
\hline Boadi et al. [13] & Ordinary Least Square Regression \\
\hline Tapanjeh [18] & Regression analysis \\
\hline Dhawan [37] & Fixed-effects Panel data model \\
\hline Abey and Velmurugan [31] & Multiple Regression Analysis \\
\hline Asimakopoulos et al. [19] & Fixed-effects Panel data model \\
\hline Pratheepan [25] & Static panel model \\
\hline Banchuenvijit [20] & Regression analysis \\
\hline Bhutta and Hasan [26] & Multivariate Regression Analysis \\
\hline Denčić-Mihajlov [36] & Fixed-effects Panel data model \\
\hline Lee [22] & Fixed-effects Panel data model \\
\hline Pervan et al. [32] & Panel data model \\
\hline Lazăr [23] & Fixed-effects Panel data model \\
\hline Devi and Devi [28] & Ordinary Least Squares (OLS) regression \\
\hline Charumathi [29] & Multiple Regression Analysis \\
\hline Chander and Aggarwal [30] & Multiple Regression Analysis \\
\hline Mijić et al. [33] & Random-effects Panel data model \\
\hline Yazdanfar [35] & Regression analysis \\
\hline
\end{tabular}


within the transport infrastructure (airports, ports, tunnels, etc.), the activities of transport agencies and manipulation of goods. The research covered active companies in the field of warehousing and support activities for transportation, i.e. a total of 748 companies, operating in a five-year period in the following ten Balkan countries: Albania, Bulgaria, Bosnia and Herzegovina, Croatia, Montenegro, North Macedonia, Romania, Serbia, Slovenia and Greece. The source of the data were financial statements, i.e. balance sheets and income statements of the companies. The data was downloaded from the TP Catalyst database with all information on public and private companies [12]. The statistical program Stata 13 was used for data processing. Based on the available TP Catalyst database, the authors were able to structure the sample solely by activity code. Access to the database did not allow for selection of the sample by further specialization. Moreover, the study only used financial data from financial statements available in the TP Catalyst database; thus, the indicators were only calculated based on these. The used database does not contain non-financial data. These limitations of the database influenced the choice of the sample and the examined indicators.

In order to analyse the prime factors determining profitability in the logistics industry, profitability was considered as a dependent variable, measured by both the Return on Assets (ROA) and Return on Equity (ROE). Leverage, company size, tangibility of assets, current ratio, asset turnover ratio, and sales growth rate were taken as independent variables.
Table 3 summarizes the research conducted by Abu-Tapanjeh [18]; Serrasqueiro [15]; Maçãs Nunes et al. [34]; Asimakopoulos et al. [19]; Burja [14]; Boadi et al. [13]; Pratheepan [25]; Denčić-Mihajlov [36]; Lazăr [23]; Abey and Velmurugan [31]; Alarussi and Alhaderi [16]; Mijić et al. [33], presenting all indicators used in this paper and the method of calculation.

The presented results in Table 4 demonstrate that the average rate of profitability measured by the return on assets was $6.46 \%$, while measured by the return on equity it was $15.71 \%$. Based on the reference value of the rate of return on assets $(\geq$ $10 \%)$ and the rate of return on equity $(\geq 15 \%)$, it can be asserted that the companies in the logistic sector achieved a satisfactory rate of return on equity during the observed period. The average value of the company size determined by assets was 6.06 , while the average value of company size determined by sales was 6.83 . The company size did not show significant value dispersions. The average value of leverage was 0.26 , which was below the reference value of 0.5 and the leverage showed significant value dispersion from -62.5 to 166.6667 . This tendency may indicate that companies in the logistic sector in the Balkan countries would take greater risks, which may create a need for a higher required profitability rate. The average value of the current liquidity ratio was 2.41 , which is in accordance with the reference value $(\geq 2)$. Logistics companies were in good financial state. It can therefore be concluded that companies have operated liquidly during the observed period and that they had 2.41 higher assets to cover the liabilities from the value of the total liabilities. The discrepancy in the sales growth rate varied from a minimum value of -1 to a

Table 3 - Profitability indicators and indicators that may impact profitability

\begin{tabular}{|l|l||}
\hline \multicolumn{1}{|c||}{ Indicators } & \multicolumn{1}{c||}{ Method of calculation } \\
\hline \hline Profitability (ROA) & ROA - Net income/Total assets \\
\hline Profitability (ROE) & ROE - Net income/Total equity \\
\hline Leverage & Total liabilities/Total assets \\
\hline Company size measured by sales & Natural logarithm of sales \\
\hline Company size measured by assets & Log of total assets \\
\hline Tangibility of assets & Net fixed assets/Total assets \\
\hline Current liquidity & Current assets/Current liabilities \\
\hline Asset turnover ratio & Net sales/Average total assets \\
\hline Sales growth rate & (Sales of current period - Sales of previous period)/Sales of previous period \\
\hline
\end{tabular}


Vuković B, et al. The Profitability Analysis of the Logistics Industry Companies in the Balkan Countries

Table 4 - Descriptive statistics

\begin{tabular}{||l|c|c|c|c||}
\hline \multicolumn{1}{|c|}{ Variables } & Mean & Std. Dev. & Min & Max \\
\hline \hline Company & 374.5 & 215.9649 & 1 & 748 \\
\hline Year & 15.5 & 1.118221 & 14 & 17 \\
\hline Leverage & 0.2600797 & 4.62517 & -62.5 & 166.6667 \\
\hline Company size measured by sales & 6.834239 & 1.8187 & -2.813411 & 12.92721 \\
\hline Company size measured by assets & 6.063262 & 2.227373 & -6.907755 & 14.71994 \\
\hline Tangibility of assets & 0.2637121 & 0.2925785 & 0 & 1 \\
\hline Current ratio & 2.410685 & 5.237596 & 0.001 & 88.1 \\
\hline Asset turnover ratio & 4.512797 & 10.12834 & 0 & 299.604 \\
\hline Sales growth rate & 27.24147 & 358.7839 & -1 & 9596.717 \\
\hline ROA & 0.0645594 & 0.9094528 & -23.306 & 4.64417 \\
\hline ROE & 0.1570689 & 0.3287092 & -1.571316 & 2.61096 \\
\hline
\end{tabular}

maximum value of $9,596.717$, which points to a large discrepancy between companies from the aspect of sales growth. Variations in the indicator value of the tangibility of assets from 0 to 1 showed that, on the one hand, there were companies who had already invested in areas which did not lead to an increase in revenue. On the other hand, the high value of this ratio indicated that there were companies with greater fixed assets, which may indicate low-level management efficiency. The average percentage of asset turnover ratio was 4.51 , a rather low value, pointing to the low efficiency in using the available funds in the companies of this field.
Table 4 displays the presented descriptive statistics of dependent and independent variables of the proposed models.

The correlation analysis of the used variables is presented in Table 5. Significant positive correlation was recorded between ROA and three indicators (Company size by sales, Company size by assets and Current ratio). On the other hand, ROE significantly correlated with five indicators. Hereby, positive correlation was recorded with Current ratio and Asset turnover ratio, and a negative one with Company size by sales, Company size by assets and Tangibility of assets.

Table 5 - Correlation matrix

\begin{tabular}{|c|c|c|c|c|c|c|c|c|c|}
\hline & Leverage & $\begin{array}{l}\text { Compa- } \\
\text { ny size } \\
\text { by sales }\end{array}$ & $\begin{array}{l}\text { Compa- } \\
\text { ny size } \\
\text { by assets }\end{array}$ & $\begin{array}{l}\text { Tangi- } \\
\text { bility of } \\
\text { assets }\end{array}$ & $\begin{array}{l}\text { Current } \\
\text { ratio }\end{array}$ & $\begin{array}{c}\text { Asset } \\
\text { turnover } \\
\text { ratio }\end{array}$ & $\begin{array}{l}\text { Sales } \\
\text { growth } \\
\text { rate }\end{array}$ & ROA & ROE \\
\hline Leverage & 1.0000 & & & & & & & & \\
\hline $\begin{array}{l}\text { Company size } \\
\text { measured by sales }\end{array}$ & -0.0045 & 1.0000 & & & & & & & \\
\hline $\begin{array}{l}\text { Company size } \\
\text { measured by assets }\end{array}$ & 0.0148 & $0.6988^{*}$ & 1.0000 & & & & & & \\
\hline Tangibility of assets & 0.0166 & -0.0408 & $0.2551^{*}$ & 1.0000 & & & & & \\
\hline Current ratio & 0.0022 & $-0.0835^{*}$ & $0.0726^{*}$ & -0.0148 & 1.0000 & & & & \\
\hline Asset turnover ratio & -0.0079 & $0.0763^{*}$ & $-0.2452^{*}$ & $-0.1571^{*}$ & -0.0401 & 1.0000 & & & \\
\hline Sales growth rate & 0.0025 & -0.0102 & -0.0184 & -0.0086 & -0.0138 & 0.0238 & 1.0000 & & \\
\hline ROA & -0.0156 & $0.0773^{*}$ & $0.1436^{*}$ & -0.0412 & $0.0854^{*}$ & -0.0322 & 0.0156 & 1.0000 & \\
\hline ROE & -0.0105 & $-0.0618^{*}$ & $-0.1968^{*}$ & $-0.2031^{*}$ & $0.1458^{*}$ & $0.1558^{*}$ & 0.0164 & $0.9388^{*}$ & 1.0000 \\
\hline
\end{tabular}

${ }^{*} p<0.05$ 
Vuković B, et al. The Profitability Analysis of the Logistics Industry Companies in the Balkan Countries

Table 6 - Variance Impact Factors of variables (VIF)

\begin{tabular}{||l|c|c|}
\hline \multicolumn{1}{|c|}{ Variable } & VIF & 1/VIF \\
\hline \hline Company size measured by sales & 4.19 & 0.238522 \\
\hline $\begin{array}{l}\text { Company size measured by } \\
\text { assets }\end{array}$ & 3.59 & 0.278909 \\
\hline Asset turnover ratio & 1.58 & 0.634081 \\
\hline Tangibility of assets & 1.33 & 0.752588 \\
\hline Current ratio & 1.06 & 0.943678 \\
\hline Sales growth rate & 1.00 & 0.998767 \\
\hline Leverage & 1.00 & 0.999213 \\
\hline
\end{tabular}

In order to detect multi-collinearity, Variance Impact Factors (VIF) were calculated for all independent variables. Based on the presented results in Table 6, it was concluded that VIF values for all variables were less than five, so multi-collinearity did not feature as a problem.

\section{EMPIRICAL RESULTS AND DISCUSSIONS}

The initial total number of observations was 2,992 . By eliminating the missing or abnormal values, the final model included 1,547 observations for Return on Assets as the dependent variable, and 1,521 observations for Return on Equity as the dependent variable. The results are summarized in Tables 7 and 8, containing the value of the coefficients, mean values, and $p$ values. The results of $F$ test, Breusch-Pagan LM test, and Hausman specification test are also presented in each table. The $\mathrm{F}$ test showed which model was more suitable for use, the fixed effects or the pooled OLS regression model. Since $p<0.05$ in both models, the fixed effects model was more convenient for this analysis. The Breusch-Pagan LM test shows which model was more applicable, either the random effects or the pooled OLS regression model. Taking into account that $\mathrm{p}<0.05$ in both models, the random effects model proved to be more convenient. Finally, the tables include the presented results of the Hausman specification test, $\mathrm{p}<0.05$ referring to the more convenient use of fixed effects model over the random effects model.

Bearing in mind that the results of the mentioned tests indicated the application of fixed-effects regression model, as supported by the research by Maçãs Nunes et al. [34]; Doğan [39]; Pratheepan [25]; Denčić-Mihajlov [36]; the following equations were formulated:

$$
\begin{aligned}
R O A_{i t}= & \beta_{0}+\beta_{1} L E V_{i t}+\beta_{2} C S_{\text {sit }}+\beta_{3} C S_{\text {ait }}+\beta_{4} T A_{i t}+ \\
& +\beta_{5} C L_{i t}+\beta_{6} A T_{i t}+\beta_{7} S G_{i t}+E_{i t} \\
R O E_{i t}= & \beta_{0}+\beta_{1} L E V_{i t}+\beta_{2} C S_{\text {sit }}+\beta_{3} C S_{\text {ait }}+\beta_{4} T A_{i t}+ \\
& +\beta_{5} C L_{i t}+\beta_{6} A T_{i t}+\beta_{7} S G i t+E_{i t}
\end{aligned}
$$

where:

$R O A_{i t}, R O E_{i t}-$ dependent variables;

$\beta_{0}$ - model constant;

$\beta_{i}-$ co-efficiency of independent variables;

$L E V, C S_{s}, C S a, T A, C L, A T, S G-$

independent (explanatory) variables;

LEVit, $C S_{\text {sit }} C S_{\text {ait }} T A_{i t} C L_{i t} A T_{i p} S G_{i t}-$

$1 \times k$ vector of observations on the

explanatory variables;

$E$ - error with a normal distribution;

$i$ - signifies each company $(i=1, \ldots \ldots, N)$;

$t$ - signifies the period of time $(t=1, \ldots ., t)$.

The first model whose results were presented in Table 7 was statistically significant with $\mathrm{p}<0.05$. According to the described results, it can be seen that the variables Company size measured by assets $(-0.0354762)$ and Tangibility of assets $(-0.2669746)$ had a statistically significant negative impact $(\mathrm{p}<0.05)$ on the profitability of the logistics company measured by return on assets. The negative impact is most often interpreted through the fact that the growth of company size through the growth of total assets can lead to the effects of diseconomies of scale. Under such circumstances, increased production costs and costs of logistics activities can trigger companies to opt for outsourcing of logistics services to logistics service providers. This is a highly common way for companies to enhance profitability and have better performance of the business with the specialization of business functions. By comparing the Return on Assets and the Return on Equity as profitability indicators of LSP clusters, according to Horngren et al. [41], it can be concluded that the Return on Equity is higher than the Return on Assets for all LSP clusters, which is a healthy sign that LSP clusters are able to earn more for their stockholders than the amount of interest they pay [41]. The negative impact of the Tangibility of assets means that high investments in fixed assets or infrastructure of the logistics companies did not result in a higher yield on invested assets and that the fixed funds were not used optimally during the observed period. The negative impact of the company size measured by assets on profitability was in accordance with the results of research conducted by Goddard et al. [27]; Doğan [39]; while the negative 
relationship between tangibility and profitability was based on research conducted by Maçãs Nunes et al. [34]; Kebewar [42]; and Mijić et al. [33].

The impact of leverage on profitability was also negative, though not statistically significant $(p>0.05)$. A negative tendency was expected, given that the growth of risks due to the use of a larger volume of other sources of financing and consequently, high-interest rates and costs, would result in a higher required rate of return, which would negatively affect the profitability of the logistics company. The negative relationship between leverage and profitability was also confirmed by Asimakopoulos et al. [19]; Charumathi [29]; Denčić-Mihajlov [36]; Pratheepan [25]; Lazăr [23]; Abey and Velmurugan [31]. More profitable companies in the logistics sector rely heavily on their own internal sources, which is in line with the pecking order theory. The payment of the high cost of debts left the companies with fewer funds for investments and the inability to exploit good investment opportunities, which, in turn, affected the ability to generate profit and growth of the company.

The results presented that the variables the company size measured by sales $(0.0275387)$, current ratio (0.0045272) and asset turnover ratio (0.0124982) had a statistically significant positive impact on the profitability of logistics company measured by return on assets $(\mathrm{p}<0.05)$. Large logistics companies usually operate in major markets, have diversification of products and activities, as well as greater opportunities to market warehousing, transport, and handling services, which leads to the growth of their profitability. The positive relationship between company size and profitability was confirmed in research carried out by Serrasqueiro [15], Bhutta and Hasan [26], and Denčić-Mihajlov [36], as well.

The liquidity growth of companies in the logistics sector, reducing liquidity risk, leads to an increase in the profitability of assets. The starting point for the successful and efficient operation of logistics companies is achieving and maintaining optimal liquidity. The achievement of optimal liquidity is vital given the nature of logistics activities, i.e. the fact that all the accompanying costs of providing services such as fuel and road charges must be financed before final payments are received. A positive relationship between the asset turnover ratio and profitability indicated that the logistics companies which optimally use their assets will also realize higher profitability. The results of Denčić-Mihajlov's research [36] and Alarussi and Alhaderi's research [16] confirmed a positive and significant relationship between company efficiency and its profitability.

The last indicator, sales growth, also had a positive, but not statistically significant ( $p>0.05$ ) impact on profitability. The positive tendency was based on the fact that sales growth leads to income growth, which represents a positive component of the net income and influenced the higher return on the logistics company engaged assets. These results are in accordance with the results of research conducted by Al-Jafari and Al Samman [24].

The results of the first model - the profitability of logistics companies measured by return on assets are presented in Table 7.

Table 7 - Dependent variable: Return on assets

\begin{tabular}{|c|c|c|c|c|c|c|}
\hline \multicolumn{7}{|c|}{ Dependent variable - Return on assets } \\
\hline Independent variables & Coef. & Std. Err. & $\mathrm{t}$ & $\mathrm{P}>\mathrm{t}$ & \multicolumn{2}{|c|}{ [95\% Conf. Interval] } \\
\hline Leverage & -0.0009239 & 0.0030491 & -0.30 & 0.762 & -0.0069078 & 0.00506 \\
\hline $\begin{array}{l}\text { Company size measured by } \\
\text { sales }\end{array}$ & 0.0275387 & 0.0147459 & 1.87 & 0.062 & -0.0014004 & 0.0564777 \\
\hline $\begin{array}{l}\text { Company size measured by } \\
\text { assets }\end{array}$ & -0.0354762 & 0.0175067 & -2.03 & 0.043 & -0.0698334 & -0.0011189 \\
\hline Tangibility of assets & -0.2669746 & 0.0552536 & -4.83 & 0.000 & -0.375411 & 0.1585383 \\
\hline Current ratio & 0.0045272 & 0.0020825 & 2.17 & 0.030 & 0.0004402 & 0.0086142 \\
\hline Asset turnover ratio & 0.0124982 & 0.0020731 & 6.03 & 0.000 & 0.0084296 & 0.0165667 \\
\hline Sales growth rate & $7.46 \mathrm{e}-06$ & 0.0000173 & 0.43 & 0.666 & -0.0000265 & 0.0000414 \\
\hline cons & 0.1993076 & 0.0796226 & 2.50 & 0.012 & 0.0430466 & 0.3555686 \\
\hline \multicolumn{7}{|l|}{$\begin{array}{ll}\mathrm{R}^{2} & 0.0986 \\
\end{array}$} \\
\hline \multicolumn{7}{|c|}{ Hausman Test $\quad \mathrm{H}=25.31(0.0007)$} \\
\hline \multicolumn{7}{|c|}{ Breusch-Pagan Test $\quad$ LM $=166.86(0.0000)$} \\
\hline \multicolumn{7}{|c|}{ F test results $\quad F(610,929)=3.99(0.0000)$} \\
\hline
\end{tabular}


Vuković B, et al. The Profitability Analysis of the Logistics Industry Companies in the Balkan Countries

Table 8 -Dependent variable: Return on equity

\begin{tabular}{|c|c|c|c|c|c|c|}
\hline \multicolumn{7}{|c|}{ Dependent variable - Return on equity } \\
\hline \multirow{2}{*}{$\begin{array}{l}\text { Independent variables } \\
\text { Leverage }\end{array}$} & \multirow{2}{*}{$\begin{array}{c}\text { Coef. } \\
0.0014069\end{array}$} & \multirow{2}{*}{$\begin{array}{c}\text { Std. Err. } \\
0.0033831\end{array}$} & \multirow{2}{*}{$\frac{\mathrm{t}}{0.42}$} & \multirow{2}{*}{$\begin{array}{c}\mathrm{P}>\mathrm{t} \\
0.678\end{array}$} & \multicolumn{2}{|c|}{ [95\% Conf. Interval] } \\
\hline & & & & & -0.0052327 & 0.0080466 \\
\hline $\begin{array}{l}\text { Company size measured } \\
\text { by sales }\end{array}$ & 0.045124 & 0.0169774 & 2.66 & 0.008 & 0.0118046 & 0.0784435 \\
\hline $\begin{array}{l}\text { Company size measured } \\
\text { by assets }\end{array}$ & -0.0502862 & 0.0202112 & -2.49 & 0.013 & -0.0899524 & -0.0106201 \\
\hline Tangibility of assets & -0.2868152 & 0.0623539 & -4.60 & 0.000 & -0.4091898 & -0.1644406 \\
\hline Current ratio & 0.0041763 & 0.0023101 & 1.81 & 0.071 & -0.0003574 & 0.00871 \\
\hline Asset turnover ratio & 0.0113792 & 0.002847 & 4.00 & 0.000 & 0.0057918 & 0.0169667 \\
\hline Sales growth rate & 0.0000107 & 0.0000342 & 0.31 & 0.754 & -0.0000564 & 0.0000778 \\
\hline _cons & 0.1857214 & 0.0910192 & 2.04 & 0.042 & 0.0070886 & 0.3643542 \\
\hline $0.0^{\prime}$ & \multicolumn{6}{|c|}{0.0749} \\
\hline Hausman Test & \multicolumn{6}{|c|}{$\mathrm{H}=28.83(0.0002)$} \\
\hline Breusch-Pagan Test LM & \multicolumn{6}{|c|}{$\mathrm{LM}=114.58(0.0000)$} \\
\hline F test results & \multicolumn{6}{|c|}{$\mathrm{F}(606,907)=3.49(0.0000)$} \\
\hline
\end{tabular}

Table 8 presents the results of the second model, also statistically significant with $\mathrm{p}<0.05$. Comparing the obtained results of the two mentioned models, it can be observed that the influence of independent variables on profitability is identical, irrespective of whether profitability is measured by return on assets or return on equity. The only exception is the variable leverage, having a positive $(0.0014069)$ and not statistically significant influence $(\mathrm{p}>0.05)$. The higher volume of borrowing from other sources positively influences the growth of the rate of return on capital, which confirms the theory of capital structure. According to the above theory, financing through the use of other sources creates savings in taxes. The positive impact of leverage on profitability could also mean that the financial strategy of logistics companies can be often focused on increasing the ability of resources to result in yield by increasing the borrowing to a reasonable level or to equally use their own and outside capital in order to finance the activities. Likewise, the logistics companies that have a higher earning power can usually rely on a larger amount of borrowing funds. The increased volume of borrowing arises from the constantly growing market demands. The positive relation between profitability and leverage was confirmed in the research conducted by Abu-Tapanjeh [18]; Mijić et al. [33].

The positive impact of liquidity on the rate of return on equity showed that the large logistics companies that effectively managed working capital and had sufficient working capital to cover the short-term liabilities, effectively managed their profitability. Efficient use of current assets indicates the optimal organization of operational activities of logistics companies, bearing in mind that large current assets could mean large stocks and receivables, which is usually the result of inefficiency of management. Efficient management leads to an optimal liquidity policy so that eliminating the risk of the inability to settle the short-term liabilities of the company. A positive relationship between profitability and liquidity was confirmed in the studies of Chander and Aggarwal [30]; Boadi et al. [13]; and Denčić-Mihajlov [36].

The greater profitability of large companies in relation to smaller companies in certain circumstances could be the result of highly efficient management strategies and management strategies of cash policies. A positive relationship between the profitability and company size measured by sales was also found in the research conducted by Maçãs Nunes et al. [34] and Yazdanfar [35]. The logistics company skill of effective assets management increases revenues that reflect on the growth of profitability. Given that the turnover of total assets can point to a pricing strategy followed by companies, it can be stated that according to the low average value of the turnover of assets (Table 4), logistics companies are characterized by high-profit margins. There were also certain logistics companies with a low share of 
fixed in total assets featuring a greater ability to respond to a rising demand, which was reflected in a higher return on equity.

The results of the second model - the profitability of logistics companies measured by return on equity - are presented in Table 8.

\section{CONCLUSION}

The primary aim of this paper was to identify the key factors that influence the company profitability in the logistics industry during the five-year period between 2013 and 2017. The authors analysed the impact of six independent indicators on the profitability of 748 companies in the field of logistic services from ten Balkan countries. The independent indicators detailed in this paper were leverage, company size, tangibility of assets, current liquidity ratio, asset turnover ratio, and sales growth rate. Profitability was considered as the dependent indicator, measured by the return on assets and return on equity. The methodology applied in this paper was the panel regression analysis in order to investigate the prime factors that have a determining influence on the profitability of the mentioned companies.

The obtained results show that the company size (measured by assets) and the tangibility of assets have a negative impact on the profitability of logistics companies. The empirical results suggest that company size (measured by sales), current liquidity and asset turnover ratio have a positive impact on the profitability of logistics companies. The impact of these indicators is the same and statistically significant, irrespective of whether profitability is measured by return on assets or return on equity. Other independent indicators analysed have no statistically significant impact on the company profitability in the logistics industry.

Despite the relevance of profitability as a key imperative for every company business, recent research has paid little attention to elements that influence the improvement of profitability of logistics companies. Dayou [5] investigated two important dimensions of logistics company performance: profitability and marketability efficiency on a sample of 22 stock-traded logistics companies in China for the year 2008. He concluded that the real problem of logistics company inefficiency was due to profitability efficiency rather than marketability efficiency, so the logistics companies should place more emphasis on activities of generating profit. The present paper focuses on key factors that have an impact on the company profitability, thereby upgrading Dayou's research.

Hofmann's manuscript discusses which financial indicators positively influence the profitability of logistic service providers. According to Hofmann et al. [6], net profit margin and asset intensity are the main financial factors of high profitability (ROA) in the field of transportation and logistics. Zeng and Wudhikarn [43] examined which factors affected profitability of companies in transportation and logistics sector, listed on the stock exchange of Thailand from 2007 to 2016. The obtained results showed that the components of intellectual capital had a statistically significant positive impact on profitability. The current research ensures a better understanding of improvement aimed towards greater profitability within logistics companies in the Balkan countries by taking into consideration factors such as liquidity, leverage, efficiency and growth.

The findings of this research may benefit the owners, managers, shareholders and employees of logistics companies, as well as policy makers. In order to make a company profitable, managers and shareholders may use these research outcomes when examining the relationship between logistics and transport costs that are directly related to the profitability of the company. Having in mind that savings in logistics costs have a greater impact on the growth of profitability than the sales growth, managers and shareholders can make the right decisions related to achieving and maintaining the company profitability. On a higher level, the results presented in this paper may also aid policy makers in the Balkan countries, as macroeconomic variables significantly affect the profitability of the economy in the field of logistics services. Finally, the results may help the stakeholders in their investment decisions and decisions on resource allocation.

Several limitations of this paper must be acknowledged, though they can also be seen as guidelines for future research. The main motivation for this examination was the lack of research on company profitability in the logistics industry in the Balkan countries. However, this paper could benefit from adding more variables to study the key factors that determine the company profitability in the logistics industry, as a possible follow-up on this paper. The final recommendation for future research is that conclusions mentioned in our research are 
pending further study in the same or other industries and sectors in order to confirm or refute the present findings. Nonetheless, this research still provides empirical evidence that supports the logistics company efforts to improve their performance and to make their business more profitable in conditions of ever-growing demands of customers and constantly changing logistic services.

\section{Doc. dr. BOJANA VUKOVIĆ}

E-mail: bojanavuk@ef.uns.ac.rs

Doc. dr. SUNČICA MILUTINOVIĆ ${ }^{1}$

(Korespondirajući autor)

E-mail: suncica@ef.uns.ac.rs

Prof. dr. VERA MIROVIĆ ${ }^{1}$

E-mail: vera.mirovic@ef.uns.ac.rs

Doc. dr. NIKOLA MILIĆEVIĆ

E-mail: milicevic.nikola@ef.uns.ac.rs

${ }^{1}$ Univerzitet u Novom Sadu

Ekonomski fakultet u Subotici

Segedinski put 9-11, 24000 Subotica, Srbija

\section{ANALIZA PROFITABILNOSTI KOMPANIJA LOGISTIČKE INDUSTRIJE U ZEMLJAMA BALKANA}

\section{APSTRAKT}

Osnovni cilj ovog rada je istraživanje faktora koji utiču na profitabilnost kompanija u logističkoj industriji tokom petogodišnjeg perioda (2013-2017). Uzorak obuhvata 748 aktivnih kompanija koje posluju u logističkoj industriji u zemljama Balkana. Imajući u vidu da je logistika važan instrument konkurentnosti i profitabilnosti poslovanja kompanije $i$ da predstavlja jednu od najprofitabilnijih industrijskih grana, ovaj rad je koristio model panel podataka sa fiksnim efektom u cilju analize profitabilnosti. Dobijeni rezultati pokazali su da četiri od šest proučavanih varijabli (veličina kompanije, opipljivost imovine, likvidnost $i$ koeficijent obrta imovine) imaju statistički značajan uticaj na profitabilnost. Rezultati daju smernice za povećanje profitabilnosti i poboljšanje performansi logističkih kompanija, imajući u vidu da su efikasan sistem planiranja, upravljanja i kontrole logističkog sistema ključne odrednice profitabilnih poslovnih aktivnosti.

\section{KLJUČNE RE ̌ I}

profitabilnost; logistička industrija; model panel podataka; zemlje Balkana;

\section{REFERENCES}

[1] Rothschild M. Shareholders pay for ROA. Strategic Finance. 2006;88(5): 26-32. Available from: https://sfmagazine.com/wp-content/uploads/sfarchive/2006/11/Shareholders-Pay-for-ROA.pdf [Accessed $29^{\text {th }}$ October 2019].

[2] Klapalova A. Reverse logistics management, drivers and profitability-metal versus other industries. In: Proceedings of the $24^{\text {th }}$ Conference on Metallurgy and Materials, 3 - 5 June 2015, Brno, Czech Republic. Available from: http://konsys2.tanger.cz/files/proceedings/21/papers/3998.pdf [Accessed 31 $1^{\text {th }}$ October 2019].

[3] Domingues ML, Reis V, Macário R. A comprehensive framework for measuring performance in a third party logistics provider. Transportation Research Procedia. 2015;10: 662-672. Available from: doi:10.1016/j.trpro.2015.09.020 [Accessed $2^{\text {nd }}$ November 2019].

[4] Škerlić S, Muha R. The importance of systems for controlling logistics costs in the supply chain: A case study from the Slovenian automotive industry. Promet - Traffic \&Transportation. 2016;28(3): 299-310. Available from: http://traffic.fpz.hr/index.php/PROMTT/article/view/ 1881/1464 [Accessed 29 $9^{\text {th }}$ March 2019].

[5] Dayou Ch. Evaluating the Profitability and Marketability of Logistics Companies in China Based on Two-stage DEA. In: Proceedings of International Conference of Information Science and Management Engineering. Proceedings of the 2010 International Conference of Information Science and Management Engineering - Volume 02, 07 - 08 August 2010. Washington DC, USA: IEEE Computer Society; 2010. p. 450-453. Available from: doi:10.1109/ISME.2010.153 [Accessed $4^{\text {th }}$ November 2019].

[6] Hofmann E, Kerstin Lampe K. Financial statement analysis of logistics service providers: Ways of enhancing performance. International Journal of Physical Distribution \& Logistics Management. 2013;43(4): 321-342. Available from: doi:10.1108/IJPDLM-08-2012-0229 [Accessed $1^{\text {st }}$ November 2019].

[7] Mothilal S, Gunasekaran A, Nachiappan SP, Jayaram J. Key success factors and their performance implications in the Indian third-party logistics (3PL) industry. International Journal of Production Research. 2012;50(9): 2407-2422. Available from: doi:10.1080/00207543.2011 .581004 [Accessed $4^{\text {th }}$ November 2019].

[8] Panayides PM. Marketing in Asia-Pacific Logistics Companies: A Discriminant Analysis between Marketing Orientation and Performance. Asia Pacific Journal of Marketing and Logistics. 2004;16(1): 42-68. Available from: doi:10.1108/13555850410765122 [Accessed $28^{\text {th }}$ October 2019].

[9] Parola F, Satta G, Panayides PM. Corporate strategies and profitability of maritime logistics firms. Maritime Economics \& Logistics. 2015;17(1): 52-78. Available from: doi:10.1057/mel.2014.18 [Accessed $4^{\text {th }}$ November 2019].

[10] Kucukaltan B, Irani Z, Aktas E. A decision support model for identification and prioritization of key performance indicators in the logistics industry. Computers in Human Behaviour. 2016;65:346-358. Available from: doi:10.1016/j.chb.2016.08.045 [Accessed $2^{\text {nd }}$ November 2019].

[11] Saripalle M. Determinants of profitability in the Indian logistics industry. Int. J. Logistics Economics and Globalisation. 2018;7(1): 13-27. Available from: doi:10.1504/ IJLEG.2018.090498 [Accessed $3^{\text {rd }}$ November 2019].

[12] Bureau van Dijk, Moody's Analytic's Company. TP Catalyst. Available from: https://www.bvdinfo.com/ en-apac/our-products/bvd-s-catalysts-solutions-by-task/ 
catalysts-solutions-by-task/tp-catalyst [Accessed $4^{\text {th }}$ April 2019].

[13] Boadi EK, Antwi S, Lartey VC. Determinants of profitability of insurance firms in Ghana. International Journal of Business and Social Research. 2013;3(3): 43-50. Available from: doi:10.18533/ijbsr.v3i3.231 [Accessed $3^{\text {rd }}$ February 2019].

[14] Burja C. Factors influencing the companies' profitability. Annales Universitatis Apulensis Series Oeconomica. 2011;13(2): 215-224. Available from: http://oeconomica.uab.ro/upload/lucrari/1320112/03.pdf [Accessed 31 ${ }^{\text {st }}$ March 2019].

[15] Serrasqueiro ZM. Growth and profitability in Portuguese companies: A dynamic panel data approach. Amfiteatru Economic. 2009;11(26): 565-573. Available from: http:// www.amfiteatrueconomic.ro/temp/Article_897.pdf [Accessed $31^{\text {st }}$ March 2019].

[16] Alarussi AS, Alhaderi SM. Factors affecting profitability in Malaysia. Journal of Economic Studies. 2018;45(3): 442-458. Available from: doi:10.1108/JES-05-20170124 [Accessed $31^{\text {st }}$ March 2019].

[17] Agiomirgianakis GM, Magoutas AI, Sfakianakis G. Determinants of profitability in the Greek tourism sector revisited: the impact of the economic crisis. Journal of Tourism and Hospitality Management. 2013;1(1): 1217. Available from: http://jthmnet.com/journals/jthm/ Vol_1_No_1_December_2013/2.pdf $\quad$ Accessed 22 nd March 2019].

[18] Abu-Tapanjeh AM. An empirical study of firm structure and profitability relationship: The case of Jordan. Journal of Economic and Administrative Sciences. 2006;22(1): 41-59. Available from: doi:10.1108/10264116200600003 [Accessed 31 $1^{\text {st }}$ March 2019].

[19] Asimakopoulos I, Samitas A, Papadogonas T. Firm-specific and economy wide determinants of firm profitability: Greek evidence using panel data. Managerial Finance. 2009;35(11): 930-939. Available from: doi:10.1108/03074350910993818 [Accessed 28 ${ }^{\text {th }}$ March 2019].

[20] Banchuenvijit W. Determinants of firm performance of Vietnam listed companies. Academic and Business Research Institute. 2012. Available from: http://aabri.com/ SA12Manuscripts/SA12078.pdf [Accessed $3^{\text {rd }}$ February 2019].

[21] Malik H. Determinants of insurance companies profitability: an analysis of insurance sector of Pakistan. Academic Research International. 2011;1(3): 315-321. Available from: http://www.savap.org.pk/journals/ ARInt./Vol.1(3)/2011(1.3-32)stop.pdf [Accessed 28 ${ }^{\text {th }}$ March 2019].

[22] Lee J. Does size matter in firm performance? Evidence from US public firms. International Journal of the Economics of Business. 2009;16(2): 189-203. Available from: doi:10.1080/13571510902917400 [Accessed 31 ${ }^{\text {st }}$ March 2019].

[23] Lazăr S. Determinants of firm performance: Evidence from Romanian listed companies. Review of Economic and Business Studies. 2016;9(1): 53-69. Available from: http://www.rebs.ro/issues/pdfs/17.pdf\#page $=53$ [Accessed $3^{\text {rd }}$ February 2019].

[24] Al-Jafari MK, Al Samman H. Determinants of profitability: Evidence from industrial companies listed on Muscat securities market. Review of European Studies. 2015;7(11): 303-311. Available from: doi:10.5539/ res.v7n11p303 [Accessed 22 ${ }^{\text {nd }}$ March 2019].

[25] Pratheepan T. A panel data analysis of profitability determinants empirical results from Sri Lankan manufacturing companies. International Journal of Economics, Commerce and Management. 2014;2(12): 1-9. Available from: http://citeseerx.ist.psu.edu/viewdoc/download?doi=10.1.1.679.9106\&rep=rep1\&type $=$ pdf $\quad$ [Accessed $3^{\text {rd }}$ February 2019].

[26] Bhutta NT, Hasan A. Impact of firm specific factors on profitability of firms in food sector. Open Journal of Accounting. 2013;2(2): 19-25. Available from: https:// file.scirp.org/pdf/OJAcct_2013042509122747.pdf [Accessed $28^{\text {th }}$ March 2019].

[27] Goddard J, Tavakoli M, Wilson J. Determinants of profitability in European manufacturing and services: Evidence from a dynamic panel model. Applied Financial Economics. 2005;18(15): 1269-1282. Available from: doi:10.1080/09603100500387139 [Accessed 28 ${ }^{\text {th }}$ March 2019].

[28] Devi A, Devi S. Determinants of firms' profitability in Pakistan. Research Journal of Finance and Accounting. 2014;5(19): 87-91. Available from: https://pdfs.semanticscholar.org/3514/1db285723ebd870c4b7ada28e26fb57a0e32.pdf [Accessed 31 ${ }^{\text {st }}$ March 2019].

[29] Charumathi B. On the determinants of profitability of Indian life insurers - An empirical study. In: Proceedings of the World Congress on Engineering (WCE), 4-6 July 2012, London, UK. The International Association of Engineers (IAENG); 2012. Volume I. Available from: https://pdfs.semanticscholar.org/fd2d/9f7474841f120d04fc701e7893e8ba491ead.pdf

[30] Chander S, Aggarwal P. Determinants of corporate profitability: An empirical study of Indian drugs and pharmaceutical industry. Paradigm. 2008;12(2): 51-61. Available from: doi:10.1177/0971890720080206 [Accessed $3^{\text {rd }}$ February 2019].

[31] Abey J, Velmurugan R. Determinants of profitability in Indian automobile industry. International Journal of Pure and Applied Mathematics. 2018;119(12): 1530115313. Available from: https://acadpubl.eu/hub/2018119-12/articles/6/1418.pdf [Accessed 22 ${ }^{\text {nd }}$ March 2019].

[32] Pervan M, Pervan I, Todorić M. Firm ownership and performance: Evidence for Croatian listed firms. International Journal of Economics and Management Engineering. 2012;6(1): 81-87. Available from: http://waset. org/publications/4833 [Accessed 22 $2^{\text {nd }}$ March 2019].

[33] Mijić K, Nuševa D, Jakšić D. The determinants of SMEs profitability in the wholesale and retail sector in Serbia. Teme. 2018;42(1): 97-111.

[34] Maçãs Nunes PJ, Serrasqueiro ZM, Sequeira TN. Profitability in Portuguese service industries: A panel data approach. The Service Industries Journal. 2009;29(5): 693707. Available from: doi:10.1080/02642060902720188 [Accessed 28 $8^{\text {th }}$ March 2019].

[35] Yazdanfar D. Profitability determinants among micro firms: Evidence from Swedish data. International Journal of Managerial Finance. 2013;9(2): 151-160. Available from: doi:10.1108/17439131311307565 [Accessed 
22 ${ }^{\text {nd }}$ March 2019].

[36] Denčić-Mihajlov K. Profitability during the financial crisis evidence from the regulated capital market in Serbia. South-Eastern Europe Journal of Economics. 2014;12(1): 7-33. Available from: http://www.asecu.gr/ Seeje/issue22/issue22-mihajlov.pdf [Accessed $3^{\text {rd }}$ February 2019].

[37] Dhawan R. Firm size and productivity differential: Theory and evidence from a panel of US firms. Journal of Economic Behavior \& Organization. 2001;44(3): 269-293. Available from: doi:10.1016/S0167-2681(00)00139-6 [Accessed 28 $8^{\text {th }}$ March 2019].

[38] Eriotis N, Stamatiadis F, Vasiliou D. Assessing accrual accounting reform in Greek public hospitals: An empirical investigation. International Journal of Economic Sciences and Applied Research. 2011;4(1): 153-184. Available from: http://ijbesar.teiemt.gr/docs/volume4 issue1/ volume4_issue1.pdf\#page $=153$ [Accessed 22 ${ }^{\text {nd }}$ March 2019].

[39] Doğan M. Does firm size affect the firm profitability? Evidence from Turkey. Research Journal of Finance and Accounting. 2013;4(4): 53-59. Available from: https:// pdfs.semanticscholar.org/5360/29a44ed8dd384cbcde67f9d60bc10cf5c775.pdf [Accessed 28 ${ }^{\text {th }}$ March 2019].

[40] Islam MS, Khan MS. The determinants of profitability of the pharmaceutical industry of Bangladesh: A random effect analysis. International Journal of Financial Research. 2019;10(2): 68-74. Available from: doi:10.5430/ ijfr.v10n2p68 [Accessed 28 ${ }^{\text {th }}$ March 2019].

[41] Horngren CT, Harrison WT, Oliver MS. Financial \& Managerial Accounting. Upper Saddle River, New York: Pearson Prentice-Hall; 2012.

[42] Kebewar M. The effect of debt on corporate profitability: evidence from French service sector. Brussels Economic Review. 2013;56(1): 43-59. Available from: doi:10.2139/ ssrn.2191075 [Accessed 3 $3^{\text {rd }}$ February 2019].

[43] Zeng S, Wudhikarn R. The Empirical Study of Relationships between Intellectual Capital, Firms' Market Value and Financial Performance of Logistics Industry of Thailand. In: Proceedings of International Conference on Information Management and Management Sciences (IMMS 2018), 24 - 26 August 2018, Chengdu, China. p. 26-32. Available from: doi:10.1145/3277139.3277170 [Accessed $1^{\text {st }}$ November 2019]. 